\title{
INSOLVENSI DALAM HUKUM KEPAILITAN DI INDONESIA \\ (Studi Putusan No.48/Pailit/2012/Pn.Niaga.Jkt.Pst Antara PT. Telekomunikasi Selular Vs PT. Primajaya Informatika)
}

\author{
Hervana Wahyu Prihatmaka \\ Fakultas Hukum Universitas Riau \\ Sunarmi \\ Fakultas Hukum Universitas Riau \\ Rahmad Hendra \\ Fakultas Hukum Universitas Riau
}

\begin{abstract}
Amendments to the Bankruptcy Law is dominant protect the interests of creditors, because it should be a provision which requires that the debtor should have to go bankrupt. This is contrary to the philosophy of universal bankruptcy. This study aims to determine the bankruptcy provisions in the bankruptcy law in Indonesia and analyze the determination of bankruptcy within the bankruptcy decision No. 48/Bankrupt/2012/PN.NIAGA.JKT.PST. This research is a normative law with normative juridical approach. The data used in this research is secondary data. This study uses literature study with qualitative analysis methods. The authors conclude, first, the provisions of bankruptcy in Indonesia is based on article 2, paragraph (1), which is when the debtor does not repay the debt that will be the bankruptcy estate will go into phase bankruptcy with two possibilities, namely (i) after being declared bankrupt (ii) Through PKPU. Secondly, Award Bankrupt Assets not yet in the stage of bankruptcy because of the Supreme Court overturned the decision of the Commercial Court Decision Number 48/Bankrupt/2012/PN.NIAGA.JKT.PST through decision Number 704K/Pdt.Sus/2012, which ended before the bankruptcy Telkomsel Meeting Debt Verification completed. Advice, first there should be amendments to the Law No. 37 of 2004 specifically test the concept of insolvency and bankruptcy. The authors are aware that this study is not perfect, so the authors hope that further research is done, to continue and resolve the issues raised in this study.
\end{abstract}

Keywords: Bankruptcy, Insolvency, the Rule of Law

\section{abstrak}

Perubahan terhadap UU Kepailitan sangat dominan melindungi kepentingan kreditur, karena itu harus ada ketentuan yang harus menyaratkan bahwa 
debitur harus bangkrut. Hal ini bertentangan dengan filosofi universal kebangkrutan. Penelitian ini bertujuan untuk menentukan ketentuan kepailitan dalam hukum kepailitan di Indonesia dan menganalisis penentuan kebangkrutan dalam putusan pailit No. 48/Pailit/2012/PN.NIAGA.JKT.PST. Penelitian ini merupakan penelitian hukum normatif dengan pendekatan yuridis normatif. Data yang digunakan dalam penelitian ini adalah data sekunder. Penelitian ini menggunakan metode studi pustaka dengan metode analisis kualitatif. Para penulis menyimpulkan, pertama, ketentuan kepailitan di Indonesia didasarkan pada pasal 2 ayat (1), yang ketika debitur tidak melunasi utangnya yang akan menjadi harta pailit akan masuk ke fase kebangkrutan dengan dua kemungkinan, yaitu (i) setelah dinyatakan bangkrut (ii) Melalui PKPU. Kedua, Aset Bangkrut Penghargaan belum dalam tahap kebangkrutan karena Mahkamah Agung membatalkan putusan Pengadilan Niaga Keputusan No. 48/Pailit/2012/PN.NIAGA.JKT.PST melalui keputusan No. 704K/Pdt.Sus/2012 yang berakhir sebelum kebangkrutan Telkomsel Rapat Verifikasi Utang selesai. Saran, pertama harus ada amandemen Undang-Undang Nomor 37 Tahun 2004 khususnya konsep insolvensi dan uji kepailitan. Penulis sadar bahwa studi ini tidak sempurna, sehingga penulis berharap bahwa penelitian lebih lanjut dilakukan, untuk melanjutkan dan menyelesaikan masalah yang diangkat dalam penelitian ini.

\section{Kata Kunci: Kepailitan, Insolvensi, Aturan Hukum}

\section{A. Pendahuluan}

Perkembangan perekonomian global membawa pengaruh terhadap perkembangan hukum terutama hukum ekonomi. Erman Radjagukguk menyebutkan, bahwa globalisasi hukum akan menyebabkan peraturanperaturan negara-negara berkembang mengenai investasi, perdagangan, jasajasa, dan bidang-bidang ekonomi lainnya mendekati negara-negara maju (Convergency). ${ }^{1}$ Persamaan ketentuan hukum berbagai negara bisa juga terjadi karena suatu negara mengikuti model negara maju berkaitan dengan institusi-institusi hukum untuk mendapatkan modal. Undang-Undang Perseroan Terbatas berbagai negara dari "Civil Law" maupun "Common Law" berisikan substansi yang serupa. ${ }^{2}$ Begitu juga dengan peraturan Pasar Modal, di mana saja tidak banyak berbeda, satu dan yang lain karena dana

\footnotetext{
${ }^{1}$ Erman Radjagukguk, Peranan Hukum Dalam Pembangunan Pada Era Globalisasi, pidato pemgukuhan diucapkan pada upacara penerimaan jabatan Guru Besar dalam bidang hukum pada Fakultas Hukum Universitas Indonesia, Jakarta, 4 Januari 1997, hlm. 8.

2 Ibid, dalam Erman Radjagukguk, David Goddard, Gonvergence in Corporations LawTowards A Facilititave Model, VUWLR vol. 26 (1996), hlm. 197-204. hlm. 7.
} 
yang mengalir ke pasar-pasar tersebut tidak lagi terikat benar dengan waktu dan batas-batas negara. Tuntutan keterbukaan (transparency) yang semakin besar, berkembangnya kejahatan internasional dalam pencucian uang (money laundering), dan “insider trading" mendorong kerjasama internasional. ${ }^{3}$

Pengaruh gejolak moneter yang terjadi di beberapa negara termasuk Indonesia sejak pertengahan tahun 1997, telah menimbulkan kesulitan yang sangat besar terhadap perekonomian nasional, terutama kemampuan dunia usaha dalam mengembangkan usahanya dan bahkan untuk mempertahankan kelangsungan kegiatan usahanya. Lebih jauh lagi, gejolak tersebut juga telah memberikan pengaruh yang besar terhadap kemampuan dunia usaha, untuk memenuhi kewajiban pembayaran mereka kepada kreditor. ${ }^{4}$

Melalui Perpu No. 1 Tahun 1998 yang kemudian dikuatkan menjadi UU No. 4 Tahun 1998 pemerintah telah melakukan perubahan, penambahan, dan penyempurnaan pasal-pasal yang terdapat dalam Faillisement Verordening Stb. 1905 No. 217 Jo.Stb.1906 No. 348. Eksistensi Peraturan Perpu tersebut lahir akibat desakan International Monetary Fund (IMF) sebagai prasyarat mendapatkan pinjaman dana untuk memulihkan kondisi perekonomian Indonesia.

Kepailitan adalah suatu proses dimana seorang debitor yang mempunyai kesulitan keuangan untuk membayar utangnya dinyatakan pailit oleh pengadilan niaga, karena debitor tersebut tidak dapat membayar

${ }^{3}$ Ibid, dalam Erman Radjagukguk, Bary A.K. Rider, Global Trends in Securities Regulation; The Changing Legal Climate, (Spring: Dickinson Journal of International Law 13, 1995), hlm. 514.

${ }^{4}$ Harian Umum Suara Merdeka, Pengumuman Kepailitan Koperasi Sumber Artha Mandiri, Tanggal 4 April 2008, hlm. 5 dalam Kristiyani, "Kajian Yuridis atas Putusan Kepailitan Koperasi di Indonesia (Studi Kasus Putusan Nomor : 01/PAILIT/2008/PENGADILAN NIAGA SEMARANG", Tesis, (Semarang: Program Studi Pasca Sarjana Universitas Diponegoro, 2008), hlm. 7.

5 Hikmahanto Juwana, Solusi Pasca pemailitan PT DI, http://www.kompas.com/kompas cetak/070/ 18/opini/3836688.htm, 18 September 2007. Letter of Intent of the Government of Indonesia to IMF (31 Oktober 1997) terdapat dalam http://img.org/ np/loi/103197.htm, 2 Agustus 2003.

Lihat juga. Arief T. Surowidjojo, Kepailitan: Sebuah Jalan Keluar? Tempo No.12/XXXII/19- $25 \quad$ Mei 2003, dalam http://www.transpara nsi.or.id/berita/beritamei2003/berita_250503.html,

lihat pula http://kompas.com/kompas-cetak/0306/27/utama/395991.htm, "IMF Setujui Pencairan 486 Juta Dollar AS," 27 Juni 2003. Sebagai perbandingan, di Argentina IMF juga menetapkan persyaratan perubahan terhadap Undang-Undang Kepailitan sebagai syarat perpanjangan pembayaran bunga utang obligasi sebesar US\$95.000.000.000,00 pada Desember 2001. http://www.vo anews.com/indonesian/archive/2002-05/a-2002-05-17-61.cfm?renderforprint $=1 \&$ textonly $=1 \& \&$ TEXTMODE $=1 \&$ CFID $=152842199 \&$ CFTO

KEN=36393862, "IMF Setujui Perpanjangan Kedua Jadwal Pembayaran Hutang Argentina,"17 Mei 2002. Dalam Siti Anisah, Studi Komparasi terhadap Perlindungan Kepentingan Kreditor dan Debitor dalam Hukum Kepailitan, Jurnal Hukum No. Edisi Khusus Vol. 16 Oktober 2009, hlm. 43 
utangnya. ${ }^{6}$ Hikmahanto Juwana berpendapat bahwa amandemen atas UUK sangat dominan melindungi kepentingan kreditor. Hal ini bisa dilihat dari syarat untuk dinyatakan pailit sebagaimana termaktub dalam Pasal 1 angka (1) UUK, yaitu adanya dua atau lebih utang dan salah satunya telah jatuh tempo. Namun, dalam amandemen UUK tersebut tidak ada satu ketentuanpun yang menyaratkan bahwa debitor harus dalam keadaan tidak mampu membayar (insolvency). Tentunya hal ini bertentangan dengan filosofi universal kepailitan dari UUK yaitu memberikan jalan keluar bagi debitor dan kreditor bilamana debitor sudah dalam keadaan tidak lagi mampu membayar utangnya. ${ }^{7}$ Demikian juga disampaikan Siti Anisah bahwa tujuan pembaruan Undang-Undang Kepailitan Indonesia belum sejalan dengan pembaruan Undang-Undang Kepailitan di banyak negara di dunia. Misalnya, Undang-Undang Kepailitan Indonesia belum mengakomodasi perlindungan terhadap kepentingan kreditor, debitor, dan stakeholders; tidak berdasarkan kepada filosofi yang melindungi kepentingan debitor solven; tidak membedakan kepailitan bagi perusahaan dan individual meskipun tujuan keduanya berbeda, serta belum memperkenankan discharge untuk kepailitan individual. ${ }^{8}$

Tujuan Undang-Undang Kepailitan yang berkembang di banyak negara di dunia adalah melindungi debitor yang jujur dengan cara membebaskan utang-utangnya (discharge). Pada perkembangan selanjutnya, tujuan hukum kepailitan juga untuk melindungi kepentingan stakeholders. ${ }^{9}$

Perubahan peraturan Kepailitan di Indonesia belum dilandasi dengan suatu filosofi yang seharusnya ada dalam Undang-Undang Kepailitan. ${ }^{10}$

Filosofi tersebut adalah debitor yang mempunyai utang lebih besar dari hartanya, sehingga hartanya harus dibagi secara proporsional kepada para kreditor, lebih baik dinyatakan pailit. Agar kreditor memperoleh pengembalian piutangnya secara maksimal, maka pemberesan harta pailit

\footnotetext{
${ }^{6}$ J. Djohansah, Pengadilan Niaga di dalam Rudi Lontoh (Ed), Penyelesaian Utang melalui Pailit dan Penundaan Kewajiban Pembayaran Utang, ( Bandung: Alumni, 2001), hlm. 23, lihat juga Pasal 1 UU No. 4 Tahun 1998.

${ }^{7}$ Hikmahanto Juwana, Hukum sebagai Instrumen Politik : Intervensi atas kedaulatan dalam proses Legislasi di Indonesia, disampaikan dalam Orasi Ilmiah Dies Natalis fakultas Hukum Universitas Sumatra Utara ke-50, Medan, 12 Januari 2004, hlm. 12.

${ }^{8}$ Siti Anisah, Op.Cit, hlm. 45.

9 Ibid, Donald R. Korobkin, Rehabilitating Values: A Jurisprudence of Bankruptcy, 91 Colum. L. Rev. 717 (1991), hlm. 763-765; David G. Carlson, Bankruptcy Theory and the Creditors' Bargain, 61 U. Cin. L. Rev. 453, (1992), hlm. 475-478; Elizabeth Warren, The Untenable Case for Repeal of Chapter 11, 102 Yale L. J. 437 (1992); Elizabeth Warren, Bankruptcy Policy, Op. Cit., hlm. 788., dalam Siti Anisah (Ed), hlm. 35.

10 Ibid, Hikmahanto Juwana, Hikmah dari Putusan Pailit AJMI, http://www.sinarha rapan.co.id/berita/0207/ 22/opi01.html, 22 Juli 2002, dalam Siti Anisah (Ed), hlm. 36.
} 
harus dilakukan secara efisien. ${ }^{11}$ Berdasarkan filosofi tersebut, debitor yang dapat dinyatakan pailit seharusnya adalah debitor yang tidak mampu (insolvent) keuangannya, artinya lebih besar utang daripada aset. ${ }^{12}$ Bagi debitor perusahaan yang asetnya lebih kecil dari utangnya, tetapi masih mempunyai harapan untuk membayar utangnya di masa depan, maka ia diberi kesempatan untuk melakukan reorganisasi. ${ }^{13}$ Dalam konteks hukum kepailitan negara-negara common law system, keadaan insolvensi debitor biasanya dibuktikan melalui insolvencytest dengan menggunakan pendekatan cash flow test atau practical insolvency. ${ }^{14}$

Pada 14 September 2012 majelis hakim Pengadilan Niaga Jakarta Pusat mengabulkan permohonan PT Prima Jaya Informatika dan menjatuhkan putusan pailit kepada PT Telekomunikasi Indonesia. ${ }^{15}$ Ini bukan pertama kalinya perusahaan yang berada dalam keadaan keuangan yang sangat sehat dinyatakan pailit oleh Pengadilan Niaga. Sebut saja pada kasus PT. Asuransi Jiwa Manulife Indonesia (AJMI) dan PT. Prudential Life Assurance.

Berdasarkan latar belakang di atas, penulis merumuskan beberapa permasalahan sebagai berikut: 1) Bagaimana ketentuan insolvensi dalam hukum kepailitan di Indonesia?; dan 2) Bagaimana penentuan insolvensi dalam putusan pailit NOMOR: 48/PAILIT/2012/PN.NIAGA.JKT.PST?

${ }^{11}$ Ibid, Elizabeth Warren, Bankruptcy Policymaking in an Imperfect World, 92 Mich. L. Rev. 336 (1993), hlm. 350; Ali M.M. Mojdehi \& Janet Dean Gertz, The Implicit Good Faith Requirement in Chapter 11 Liquidations: A Rule in Search of a Rationale? 14 Am. Bankr. Inst. L. Rev. 143 (2006), hlm. 155-156, dalam Siti Anisah (Ed), hlm. 36.

${ }^{12}$ Ibid, Hikmahanto Juwana, Hikmah..., Loc. Cit.; Hikmahanto Juwana, "Reform of Economic Laws and Its Effects on the Post-Crisis Indonesian Economy," The Developing Economies, XLIII- 1, 72-90 (Maret 2005), hlm. 77, dalam Siti Anisah (Ed), hlm. 36.

${ }^{13}$ Ibid, Lynn M. LoPucki, "A Team Production Theory of Bankruptcy Reorganization," 57 Vand. L. Rev. 741 (April, 2004), hlm. 743; Intan Eow, "The Door to Reorganisation: Strategic Behaviour or Abuse of Voluntary Administration?" 30 Melb. U. L. Rev. 300 (Agustus 2006), hlm. 302 - 303. Dalam Siti Anisah (Ed), hlm. 36.

${ }^{14}$ Andrew R Keay, Insolvency: Personal and Corporate Law and Practice, LawBook Company Service, Sydney, 1994, hlm. 3. Dalam Sunarmi, Prinsip Keseimbangan Dalam Hukum Kepailitan di Indonesia Edisi II "A critical review on bankcruptcylaw: towards the bankcruptcy laws that protect creditors and debitors interest, (Medan: Sofmedia, 2008), hlm. 381.

${ }^{15} \mathrm{http}: / /$ www.jurnal hukum.com/2-hal-yang-mengakibatkan-telkomsel-pailit/, diakses tanggal 03 Januari 2013 


\section{B. Pembahasan}

\section{Ketentuan Insolvensi dalam Hukum Kepailitan di Indonesia}

a. Kelemahan-Kelemahan Hukum Kepailitan

Pembahasan mengenai konsep insolvensi dalam hukum kepailitan di Indonesia berangkat dari serangkaian koreksi tentang kelemahan-kelemahan hukum kepailitan. Kelemahan-kelemahan yang dimaksud sebagai berikut :

\section{1) Kelemahan Faillissmentsverodening}

Pertama, proses pemeriksaan kepailitan memakan waktu yang lama. Faillissmentsverodening tidak ada menentukan berapa lama batasan waktu untuk menyelesaikan perkara kepailitan. Henry Lie A Weng menyebutkan bahwa peraturan-peraturan tersebut tidak praktis, rumit, dan berlangsung terlalu lama dan memakan biaya yang tidak murah. ${ }^{16}$

Kedua, Pemeriksaan pembukuan debitor jarang dilaksanakan. Setelah kemerdekaan, hakim tidak melakukan pemeriksaan atas pembukuan debitor. ${ }^{17}$

Ketiga, Gijzeling ditiadakan. Meskipun Faillissmentsverodening mengatur tentang lembaga paksa badan, namun dalam prakteknya hal ini tidak dilaksanakan oleh pengadilan.

\section{2) Kelemahan UU No. 4 Tahun 1998}

Pertama, Pengertian utang tidak Komprehensif. Hal ini terlihat pada kecenderungan dunia usaha mengonstruksikan sengketa-sengketa niaga yang berkaitan niaga yang berkaitan dengan kepailitan dan PKPU, bukan lagi sebagai wanprestasi atau perbuatan melawan hukum, melainkan dipaksa mendalilkannya dengan utang yang telah tempo dan dapat ditagih, yang kemudian diajukan proses pailit. ${ }^{18}$

Kedua, Pembuktian sederhana. Pasal 1 ayat (1) jo. Pasal 6 ayat (3) mensyaratkan pembuktian sederhana dalam menentukan dikabulkan atau tidaknya suatu permohonan kepailitan. Namun UUK tidak memberikan penjelasan yang rinci mengenai bagaimana pembuktian sederhana ini dilakukan dalam memeriksa permohonan pailit, kecuali menyatakan bahwa pembuktian sumir pada umumnya.

Ketiga, Pemeriksaan yang terlalu cepat dan efisien. Putusan atas permohonan pernyataan pailit harus ditetapkan dalam jangka waktu paling lambat 30 (tiga puluh) hari sejak permohonan pernyataan pailit didaftarkan.

\footnotetext{
${ }^{16}$ Henry Lie Aweng, Tinjauan Pasal demi Pasal Fv (FaillissmentsverodeningS 1905No 217 jo s 1906 No. 348 Jts Perpu No. 1 Tahun 1998 dan UU no 4 Tahun 1998, Medan, hlm. 14 Dalam Sunarmi, Prinsip Keseimbangan..., Op.Cit. hlm. 179.

${ }^{17} \mathrm{Ibid}$.

${ }^{18}$ Ibid, hlm. 291.
} 
Keempat, Tidak adanya perbedaan antara debitor insolven dan solven. UUK tidak mencantumkan keadaan insolven asal syarat pailit sebagaimana Pasal 1 ayat (1) Jo. Pasal 6 ayat (3) UUK terpenuhi, maka debitor tersebut dinyatakan pailit.

3) Kelemahan UU No. 37 tahun 2004

Pertama, Tidak adanya jumlah minimal utang. UUK dan PKPU tidak memberikan batasan jumlah minimal utang yang didalilkan oleh pemohon pailit dan termohon pailit, hal ini akan menimbulkan celah hukum untuk mengajukan permohonan pailit.

Kedua, Tidak adanya insolvensi tes. Debitor yang masih memiliki kekayaan yang cukup untuk membayar utang-utangnya dapat dinyatakan pailit oleh pengadilan karena tidak membayar utang dengan memenuhi ketentuan pasal 2 ayat (1) UUK dan PKPU. Hal ini tentu saja merugikan perusahaan yang masih solven. Akibatnya, banyak investor tidak percaya lagi untuk menanamkan investasinya di Indonesia.

\section{b. Pengertian Insolvensi}

Insolvensi (insolvency) dalam kamus bahasa Inggris berarti: ketidak mampuan membayar utang. ${ }^{19}$ Pengertian insolvensi (insolvency) menurut Fridmen, Jack P dalam Munir Fuady adalah: ${ }^{20}$

"Ketidak sanggupan untuk memenuhi kewajiban finansial ketika jatuh waktu seperti layaknya dalam bisnis, atau kelebihan kewajiban dibandingkan dengan asetnya dalam waktu tertentu”.

Berikut adalah beberapa pengertian insolvensi.

\section{1) Menurut Faillissmentsverodening}

Dasar insolvensi menurut Faillissmentsverodening diartikan sebagai keadaan "berhenti membayar", terdapat pada Pasal 1 ayat (1). Tidak ada pertimbangan oleh hakim bahwa debitor baru sekali atau dua kali tidak membayar utangnya yang telah jatuh temponya dapat dijatuhkan pailit. Sedangkan menurut Tirtaatmidjaja, bahwa debitor yang baru sekali saja menolak pembayaran maka hal itu belumlah merupakan suatu keadaan berhenti membayar. ${ }^{21}$

2) Menurut UU No. 4 Tahun 1998

${ }^{19}$ Peter Salim, Slim's Ninth Collegiate English - Indonesian Dictionary, (Jakarta: Modern English Press, 2000), hlm. 754.

${ }^{20}$ Munir Fuady, Hukum Pailit dalam Teori dan Praktek, (Bandung: Citra Aditya Bakti, 1999), hlm. 135.

${ }^{21}$ M. H. Tirtaarmadjaja, Pokok-pokok Hukum Perniagaan, (Jakarta: Djambatan, 1970), hlm 128. 
Dasar insolvensi menurut UU No. 4 Tahun 1998 diartikan sebagai keadaan "tidak membayar", tertuang dalam Pasal 1 angka (1). Dasar insolvensi diartikan sebagai "tidak membayar", Prajoto mengartikan sebagai $^{22}$ : menolak untuk membayar; cidera janji atau wanprestasi; keadaan tidak membayar tidak sama dengan keadaan kekayaan debitor tidak cukup untuk melunasi seluruh utangnya; tidak diharuskan debitor memiliki kemampuan untuk membayar (onvermogen) dan memikul seluruh utangnya; atau istilah tidak membayar harus diartikan sebagai naar de letter, yaitu debitor pada saat diajukan permohonan pernyataan pailit telah sama sekali berhenti membayar utangnya.

\section{3) Menurut UU No. 37 Tahun 2004}

Dasar insolvensi menurut UU No. 37 Tahun 2004 diartikan sebagai keadaan "tidak membayar lunas", tertuang dalam Pasal 2 ayat (1). Keadaan tidak membayar lunas diartikan sebagai sudah membayar sekali, dua kali, dan seterusnya tetapi tidak seluruhnya, atau debitor sudah membayar pokoknya tetapi belum membayar bunganya.

\section{c. Tahap Fase Insolvensi}

Untuk masuk ke dalam tahap insolvensi ada dua kemungkinan yaitu :

1) setelah dinyatakan pailit. Keadaan insolvensi terjadi dengan sendirinya tanpa putusan hakim apabila dalam rapat pencocokan utang tidak ditawarkan accord, atau ada accord tetapi tidak disetujui oleh rapat verifikasi, atau ada accord yang sudah disetujui tetapi tidak mendapat homologasi dari hakim pemitus kepailitan, atau ada accord yang sudah dihomologasi, tetapi ditolak oleh hakim banding; dan

2) melalui PKPU. Apabila, dalam waktu 270 hari setelah putusan pembayaran sementara diucapkan rencana perdamaian tersebut tidak diterima oleh para kreditor, atau perdamaian tersebut tidak disahkan oleh pengadilan niaga, atau tidak ada persetujuan apapun yang telah dicapai, hakim pengawas akan memberitahukan pengadilan niaga kemudian harus menyatakan debitor pailit. Dalam keadaan inilah debitor masuk fase insolvensi.

\section{d. Permasalahan Terkait Konsep Insolvensi di Indonesia}

1) Terhambatnya iklim Investasi di Indonesia.

Bagi negara berkembang, untuk bisa mendatangkan investor setidaktidaknya dibutuhkan tiga syarat yaitu; pertama, ada economic opportunity

\footnotetext{
${ }^{22}$ Pradjoto, "RUU Kepailitan ditinjau dari aspek Perbankan", Makalah yang disampaikan dalam Seminar Sosialisasi RUU tentang Kepailitan oleh BPHN dan ELLIPS PROJECT, Jakarta, 27-2 Juli 1999, hlm. 5.
} 
(investasi mampu memberikan keuntungan secara ekonomis bagi investor); kedua, political stability (investasi akan sangat dipengaruhi stabilitas politik); dan ketiga, legal certainty atau kepastian hukum.

Regulasi di Indonesia dinilai sangat lemah dan ini nyaris mencakup semua aspek. Regulasi yang lemah menyebabkan ketidak pastian hukum dan dalam ketidak pastian hukum, pungutan liar dan berbagai tindak korupsi merajalela sehingga arus investasi Indonesia menjadi tidak kondusif. Hal ini dibuktikan hasil beberapa lembaga penelitian Pemeringkat Daya Saing seperti $^{23}$ : International Institute for Management Development (IMD), Political and Economic Risk Consultancy (PERC), Japan Bank for International Cooperation (JBIC), World Investment Report 2002, World Bank, AC Nielsen, dan UNDP (The United Nations Development Programs) yang secara kompak menyatakan Indonesia dalam kelompok negara yang paling tidak diminati dalam investasi. Sebagai contoh masalah ketidakpastian hukum, tahun 2004, PT Prudential Life Assurance (Prudential), perusahaan asuransi dari Inggris ini harus jatuh bangun menghadapi serangkaian gugatan dan permohonan pailit. Ketidak pastian hukum dalam perkara ini disebabkan tidak jelasnya pengaturan tentang konsep insolvensi dan tidak adanya insolvensi tes, sehingga sulit dibedakan peristiwa berhenti membayar karena tidak mampu membayar dan berhenti membayar karena tidak mau membayar. Peristiwa ini sebenarnya lebih mengarah pada perbuatan cidera janji yang semestinya diselesaikan melalui gugatan perdata biasa. ${ }^{24}$

2) Tidak tercapainya perlindungan kreditor, debitor, dan stakeholder secara seimbang.

Undang-undang Kepailitan harus memberikan perlindungan yang seimbang antara kreditor, debitor, dan stakeholder. Undang-undang kepailitan mulanya bertujuan untuk melindungi para kreditor dengan memberikan jalan yang jelas dan pasti untuk menyelesaikan utang yang tidak dapat dibayar. ${ }^{25}$ Namun, di sisi lain hukum kepailitan seharusnya juga dapat melindungi debitor yang beritikad baik untuk membayar utangnya. Perlindungan terhadap stakeholders mempunyai suatu tujuan imperatif, yaitu bisnis harus dijalankan sedemikian rupa agar hak dan kepentingan

${ }^{23}$ Budiman Ginting, "Kepastian Hukum Dan Implikasinya Terhadap Pertumbuhan Investasi di Indonesia, makalah yang disampaikan dalam Pidato Pengukuhan Guru Besar Tetap, Universitas Sumatera Utara, medan, 20 September 2008, hlm. 14-16

${ }^{24}$ http://ocw.usu.ac.id/course/download/10430000019-hukum-transaksi-bisnisinternasional/hk_607_slide_kepastian_hukum_dalam_transaksi_bisnis_internasional_dan_i mplikasinya_terhadap_kegiatan_investasi_di_indonesia.pdf.

25 Erman Radjagukuguk. Latar Belakang dan Ruang Lingkup Undang-Undang Nomor 4 Tahun 1998 tentang Kepailitan, di dalam Ruddhy Lontoh (Ed.), Penyelesaian Utang..., Op.Cit. hlm. 181. 
stakeholders dijamin, diperhatikan, dan dihargai dalam suatu kegiatan bisnis. Sebabnya, berbagai pihak tersebut dipengaruhi dan dapat mempengaruhi keputusan dan tindakan bisnis. ${ }^{26}$

3) Beresiko mengancam stabilitas pembangunan ekonomi Indonesia.

Berbagai studi tentang hubungan hukum dan pembangunan ekonomi menunjukan bahwa pembangunan ekonomi tidak akan berhasil tanpa pembaruan hukum. $^{27}$ Stabilitas pembangunan perekonomian adalah prasyarat dasar untuk tercapainya peningkatan kesejahteraan rakyat melalui pertumbuhan yang tinggi dan peningkatan kualitas pertumbuhan. ${ }^{28}$ Dengan terhambatnya investasi sebagai akibat dari tidak adanya kepastian hukum dan tidak adanya perlindungan yang seimbang antara debitor, kreditor, dan pihak yang berkepentingan akan mengancam stabilitas pembagunan perekonomian secara keseluruhan.

\section{Penentuan Insolvensi dalam Putusan Pailit Nomor: 48/Pailit/2012/Pn.Niaga.Jkt.Pst \\ a. Duduk Perkara}

Permasalahan yang terdapat dalam putusan ini adalah permohonan pailit yang diajukan oleh PT. Prima Jaya Informatika terhadap PT. Telekomunikasi Selular atas utang yang jatuh tempo terhadap Puchase Order PO/PJI-AK/VI/2012/00000027 tertanggal 20 Juni 2012 dan No. $\mathrm{PO} / \mathrm{PJI}-\mathrm{AK} / \mathrm{VI} / 2012 / 00000028$ tertanggal 21 Juni 2012 senilai total tagihan Rp 5.260.000.000,00 (lima miliar dua ratus enam puluh juta Rupiah). Dalam perjanjian kerjasama disepakati Termohon pailit berkewajiban untuk menyediakan voucher isi ulang bertema khusus olahraga dalam jumlah sedikit-dikitnya $\mathrm{Rp}$ 120.000.000,00 (seratus dua puluh juta rupiah) yang terdiri dari voucher isi ulang $\mathrm{Rp}$ 25.000,00 (dua puluuh lima ribu rupiah) dan voucher isi ulang $\mathrm{Rp}$ 50.000,00 (lima puluh ribu rupiah) dan kartu prabayar bertema khusus olahraga dalam jumlah sedikitnya 10.000.000 (sepuluh juta) setiap tahun untuk dijual oleh PT. Prima Jaya Informatika.

Namun atas dua Puchase Order tersebut, Telkomsel memutuskan untuk menghentikan sementara alokasi produk Prima. Dalam eksepsi,

${ }^{26}$ Lihat A Sony Keraf, Etika Bisnis Tuntutan dan Relevansinya, (Yogyakarta: Kanisius, 1998), hlm. 89, dalam Siti Anisah (Ed), Op.cit, hlm. 35.

27 Erman Rajagukguk, Peranan Hukum Di Indonesia: Menjaga Persatuan Bangsa, Memulihkan Ekonomi Dan Memperluas Kesejahteraan Sosial*) Disampaikan Dalam Rangka Dies Natalis Dan Peringatan Tahun Emas Universitas Indonesia (1950-2000), Kampus Ui-Depok, 5 Februari 2000.

${ }^{28} \mathrm{http}: / /$ webcache.googleusercontent.com/search?q=cache:tjyj3m0VnpAJ:www.bappe nas.go.id/getfileserver/node/169/+faktor+yang+mempengaruhi+stabilitas+ekonomi+pdf\&cd $=3 \& \mathrm{hl}=\mathrm{en} \& \mathrm{ct}=\mathrm{clnk}$, diakses tanggal 9 Juni 2013 . 
Telkomsel menyatakan bahwa pengadilan niaga pada pengadilan negeri jakarta pusat tidak berwenang memeriksa dan mengadili perkara a quo, permohonan pernyataan pailit kabur (exceptio obscurum libelum), dan pemohon pailit tidak memiliki alasan hak untuk mengajukan permohonan pernyataan pailit, karena tidak ada utang yang jatuh tempo (exeptio onrechtmatige of ongegrond). Selain itu, juga disampaikan wanprestasi Prima Jaya atas Perjanjian Kerjasama, yaitu: Prima Jaya gagal membangun komunitas Prima dengan jumlah anggota 10 juta dalam setahun perjanjian atau hingga juni 2012, Gagal menjual produk Telkomsel tersebut hanya di komunitas Prima, karena ternyata menjual di luar komunitas Prima. Gagal membayar purchase order NO. PO/PJI-AK/V/2012/00000026 tangal 9 Mei 2012 yang mengakibatkan kerugian bagi Telkomsel.

Telkomsel juga mempunyai utang kepada PT. Extent Media Indonesia atas pelaksanaan kerja sama layanan Mobile Data Content, senilai total tagihan tersebut sebesar Rp 40.326.213.794,00 (empat puluh miliar tiga ratus dua puluh enam juta dua ratus tiga belas ribu tujuh ratus sembilan puluh empat rupiah).

\section{b. Pertimbangan Hakim}

Mengenai adanya satu utang yang telah jatuh tempo dan dapat ditagih. Pengertian utang dalam UUK merupakan pengertian utang dalam arti luas, dengan demikian, dengan mengacu pada ketentuan pasal 1458 KUH Perdata dalil bantahan Termohon Pailit yang menyatakan bahwa Purchase Order Pemohon Pailit yang ditolak oleh Termohon Pailit bukan merupakan utang yang jatuh tempo dan dapat ditagih sehingga permohonan pernyataan pailit yang diajukan tidak ada dasar hukumnya dan tidak memiliki alas hak untuk mengajukan permohonan pailit harus dinyatakan ditolak.

Mengenai adanya dua kreditor atau lebih. Menimbang pasal 1888 KUH Perdata, Termohon tidak dapat membuktikan telah melakukan pembayaran atas tagihan PT. Extent Media Indonesia periode bulan Agustus sampai dengan Oktober 2011 dan karenanya terbukti secara sah dan meyakinkan bahwa Termohon Pailit memiliki kewajiban kepada kreditor lainnya selain Termohon Pailit. (vide Putusan MARI No: 3609/K/Pdt/1985 tertanggal 4 Desember 1987).

Menimbang bahwa dari uraian pertimbangan di atas ternyata Pemohon Pailit dapat membuktikan terdapatnya fakta atau keadaan yang terbukti secara sederhana bahwa persyaratan untuk dinyatakan pailit sebagaimana dimaklsud dalam pasal 2 ayat (1) UUK telah terpenuhi sehingga permohonan pernyataan pailit beralasan hukum dan karenanya harus dikabulkan pasal ayat (4) UUK.

\section{c. Putusan Pengadilan Niaga}


Hakim Pengadilan Niaga Jakarta Pusat pada tanggal 14 September 2012 memutuskan dalam eksepsi untuk menolak eksepsi Termohon Pailit untuk seluruhnya. Dalam pokok perkara mengabulkan Permohonan Penyataan Pailit dari Pemohon Pailit terhadap Termohon Pailit untuk seluruhnya dan menyatakan Termohon, Pailit dengan segala akibat hukumnya.

\section{d. Putusan Mahkamah Agung No. 704 K/Pdt.Sus/2012}

Pada tanggal 21 November 2012 Majelis Hakim memutuskan kasasi yang diajukan Tekomsel. Putusan ini mengabulkan permohonan kasasi dari Pemohon Kasasi, membatalkan putusan Pengadilan Niaga Jakarta Pusat Nomor: 48/Pailit/2012/Pn.Niaga.Jkt.Pst.

\section{e. Analisa Kasus}

1) Tentang Persyaratan Permohonan Pernyataan Pailit.

Mengenai adanya kreditor lain, penulis berpendapat bahwa pertimbangan majelis hakim yang menyatakan bahwa Extent media sebagai kreditor lain adalah tidak tepat dan cenderung inkonsisten karena bukti-bukti tentang kreditor lainnya yang hanya diajukan photocopy dapat disetujui oleh pengadilan niaga, sementara bukti tentang pelunasan utang terhadap kreditor lainnya tersebut dengan begitu saja ditolak dengan menyatakan photocopy. Di sini, hakim melanggar asas imparsialitas dan asas audi et alteram partem.

Mengenai adanya utang, penulis berpendapat bahwa adanya utang dalam kasus kepailitan ini tidak dapat dibuktikan secara sederhana. Telkomsel membantah adanya utang dengan alasan exceptio nonadipleti contractus, yaitu karena didahului dengan wanprestasi yang dilakukan oleh pemohon pailit. Sehingga tidak ada utang yang dapat dijadikan syarat permohonan pernyataan pailit atau setidak-tidaknya permohonan pailit harus ditolak karena eksistensi utang yang dijadikan pokok perkara ini sangat rumit sehingga harus dibuktikan terlebih dahulu melalui Pengadilan Negeri.

Mengenai syarat jatuh tempo dan dapat ditagih, penulis berpendapat bahwa jatuh tempo utang yang dimaksudkan dalam perkara ini tidak dapat ditentukan karena utang yang dimaksud tidak dapat dibuktikan secara sederhana dan harus dibuktikan terlebih dahulu melalui Pengadilan Negeri.

2) Tentang Prosedur Permohonan Pailit.

Penulis berpendapat bahwa prosedur permohonan pernyataan pailit yang diajukan oleh Prima Jaya telah sesuai dengan ketentuan prosedur permohonan pernyataan pailit sebagaimana diatur dalam Undang-Undang Nomor 37 Tahun 2004 tentang Kepailitan dan Penundaan Kewajiban Pembayaran Utang. 
3) Tentang Penentuan Insolvensi.

Penulis mendasarkan pada ketentuan pasal 2 ayat (1) menurut UU No. 37 Tahun 2004. Insolvensi diartikan sebagai "tidak membayar lunas" utangnya. Insolvensi muncul ketika Telkomsel menolak menerbitkan Purchase Order No. PO/PJI-AK/VI/2012/00000027, dan Purchase Order No. PO/PJI-AK/VI/2012/00000028. Berhentinya penerbitan alokasi produk oleh Telkomsel adalah suatu keadaan tidak membayar lunas atas utang dalam arti luas yaitu prestasi Telkomsel sebagaimana dimaksud dalam perjanjian kerjasama, sehingga menjadi dasar insolvensi. Menurut pasal 144 UUK, debitor yang telah dinyatakan pailit berhak untuk menawarkan perdamaian kepada semua kreditor. Telkomsel secara resmi mengajukan proposal perdamaian untuk menyelesaikan utang-utangnya kepada kreditor. Dalam proposal perdamaian yang diajukan pada hari Senin, 22 Oktober 2012, Telkomsel mengaku siap menyelesaikan seluruh kewajibannya. Untuk menyelesaikan semua utang-utangnya tersebut. ${ }^{29}$

Pencocokan piutang dilakukan dalam rapat kreditor, setelah putusan pailit dibacakan sesuai dengan pasal 113 ayat (1) UUKPKPU. Hingga Rapat Pencocokan Piutang yang digelar 31 Oktober 2012, tercatat ada 176 pihak yang mengajukan tagihan kepada tim kurator Telkomsel, dengan nilai tagihan mencapai Rp 14 triliun. ${ }^{30}$ Namun, hanya 46 pihak yang diakui oleh Telkomsel sebagai kreditornya dengan nilai tagihan Rp 3,15 triliun (atau 81,9 juta dollar AS). ${ }^{31}$ Rapat verifikasi atau pencocokan utang Telekomunikasi Seluler (Telkomsel), ditunda hingga tiga pekan dari tanggal 31 oktober 2012, karena debitor belum siap karena masih banyak hal yang perlu diselesaikan berkaitan dengan tagihan kreditor dalam rapat kreditor. ${ }^{32}$

Secara kronologis, 16 juli 2012 Primajaya mengajukan gugatan pailit. 14 September 2012, Hakim Pengadilan Niaga memutuskan Telkomsel Pailit. 21 September 2012, Telkomsel mengajukan kasasi. 22 Oktober 2012 Telkomsel mengajukan proposal perdamaian. 31 Oktober 2012, Rapat kreditor pertama, namun karena ada beberapa permasalahan yang harus diselesaikan Telkomsel meminta Rapat Kreditor Diundur 3 (tiga) minggu kemudian untuk mempersiapkan diri. 21 November 2012, Mahkamah Agung membatalkan putusan Pengadilan Niaga sekaligus berarti Telkomsel batal Pailit. 29 Januari $2013^{33}$, Primajaya mengajukan Peninjauan. Berdasarkan

\footnotetext{
${ }^{29} \mathrm{http} / / /$ nasional.kontan.co.id/news/telkomsel-ajukan-proposal-perdamaian, diakses tang-gal 9 Juni 2013.

${ }^{30}$ http://tekno.kompas.com/read/2012/11/02/16472299/Kurator.Siap.Pertemukan.Telk omsel. dengan.Prima.Jaya, diakses tanggal 9 Juni 2013.

${ }^{31}$ Ibid. diakses tanggal 9 Juni 2013.

${ }^{32} \mathrm{http} / / /$ www.bisnis-jatim.com/index.php/2012/10/31/pailit-telkomsel-debitur-belum-siapverifikasi-utang-ditunda/, diakses tanggal 9 Juni 2013.

${ }^{33} \mathrm{http}: / /$ www.bisnis-kepri.com/index.php/2013/02/prima-jaya-ajukan-peninjauan- kembalitelkomsel-masih-teran cam-pailit/, diakses tanggal 9 Juni 2013.
} 
pada kronologi sebagaimana dijelaskan di atas, dapat disimpulkan bahwa harta pailit belum sampai pada fase insolvensi.

\section{Penutup}

\section{Kesimpulan} bahwa:

Berdasarkan pembahasan yang disampaikan penulis menyimpulkan

a. Ketentuan insolvensi di indonesia di dasarkan pada pasal 2 ayat (1) yaitu ketika debitor "tidak membayar lunas" utangnya. Harta pailit akan masuk ke dalam fase insolvensi dengan dua kemungkinan yaitu setelah dinyatakan pailit dan melalui PKPU. Ketentuan insolvensi dan hukum kepailitan di Indonesia masih menimbulkan ketidakpastian hukum yang menimbulkan permasalahan-permasalahan yang berkaitan dengan pembangunan ekonomi Indonesia, yaitu terhambatnya iklim investasi di Indonesia, tidak tercapainya perlindungan kreditor, debitor, dan stakeholder secara seimbang, dan beresiko mengancam stabilitas pembangunan ekonomi Indonesia.

b. Syarat-syarat pernyataan pailit dalam Putusan Pengadilan Niaga Nomor 48/Pailit/2012/Pn.Niaga.Jkt.Pst tidak dipertimbangkan dengan tepat oleh Majelis Hakim Pengadilan Niaga, khususnya tentang adanya kreditor lain dan adanya utang yang menjadi pokok sengketa. Harta pailit dalam Putusan Pengadilan Niaga Nomor 48/Pailit/2012/Pn.Niaga.Jkt.Pst belum sampai dalam fase insolvensi.

\section{Saran}

Untuk menyelesaikan masalah-masalah yang ditimbulkan akibat ketidakpastian hukum karena konsep insolvensi yang tidak jelas dan tidak adanya insolvency test penulis mengharapkan adanya pembaruan hukum di bidang kepailitan, khususnya amandemen Undang-Undang Nomor 37 Tahun 2004 tentang UUK dan PKPU, sehingga konsep insolvensi menjadi jelas dan selaras dengan perkembangan pengaturan kepailitan di banyak negara di dunia.

\section{Daftar Pustaka}

\section{A. Buku}

Fuady, Munir, 1999. Hukum Pailit dalam Teori dan Praktek, Bandung: Citra Aditya Bakti. 
Lontoh, Rudhy A, et.al., 2001. Penyelesaian Utang Piutang Melalui Kepalitan atau Penundaan Kewajiban Pembayaran Utang, Bandung: Alumni.

Sunarmi, 2008. Prinsip Keseimbangan Dalam Hukum Kepailitan di IndonesiaEdisi II "A critical review on bankcruptcylaw: towards the bankcruptcy laws that protect creditors and debitors interest, Medan: Sofmedia.

Tirtaarmadjaja, M. H., 1970. Pokok-pokok Hukum Perniagaan, Jakarta: Djambatan.

\section{B. Jurnal/Kamus/Makalah}

Ginting, Budiman, 2008, Kepastian Hukum Dan Implikasinya Terhadap Pertumbuhan Investasi di Indonesia, makalah yang disampaikan dalam Pidato Pengukuhan Guru Besar Tetap, Universitas Sumatera Utara, Medan, 20 September.

Juwana, Hikmahanto, 2004, "Hukum sebagai Instrumen Politik: Intervensi atas kedaulatan dalam proses Legislasi di Indonesia", disampaikan dalam Orasi Ilmiah Dies Natalis fakultas Hukum Universitas Sumatra Utara ke-50, Medan, 12 Januari.

Kristiyani, 2008, "Kajian Yuridis atas Putusan KepailitanKoperasi di Indonesia (Studi Kasus Putusan Nomor:01/PAILIT/2008/PENGADILAN NIAGA SEMARANG", Tesis,Program Studi Pasca Sarjana Universitas Diponegoro, Semarang, Peter Salim, 2000, Slim's Ninth Collegiate EnglishIndonesian Dictionary, Modern English Press, Jakarta.

Pradjoto, 1999, RUU Kepailitan ditinjau dari aspek Perbankan, Makalah yang disampaikan dalam Seminar Sosialisasi RUU tentang Kepailitan oleh BPHN dan ELLIPS PROJECT, Jakarta, 27-28 Juli.

Radjagukguk, Erman, 1997, "Peranan Hukum Dalam Pembangunan Pada Era Globalisasi", pidato pemgukuhan diucapkan pada upacara penerimaan jabatan Guru Besar dalam bidang hukum pada Fakultas Hukum Universitas Indonesia, Jakarta, 4 Januari.

$$
\text { , 2000, "Peranan Hukum Di Indonesia : Menjaga Persatuan }
$$

Bangsa, Memulihkan Ekonomi Dan Memperluas Kesejahteraan Sosial", Disampaikan Dalam Rangka Dies Natalis Dan Peringatan Tahun Emas Universitas Indonesia (1950-2000), Kampus Ui-Depok, 5 Februari.

Siti Anisah, 2009, Studi Komparasi terhadap Perlindungan Kepentingan Kreditor dan Debitor dalam Hukum Kepailitan, Jurnal Hukum No. Edisi Khusus Vol. 16 Oktober. 


\section{Peraturan Perundang-Undangan}

Kitab Undang-Undang Hukum Perdata, Terjemahan R. Subekti.

Tjitrosudibio. 1999. Kitab Undang-Undang Hukum Perdata, Pranadya Paramita, Jakarta.

Faillisement Verordening Staatsblad. 1905 Noor 217 Jo. Staatsblad.1906No. 348.

Peraturan Pemerintah Pengganti Undang-Undang Nomor 1 Tahun 1998 tentang Perubahan AtasUndang-Undang tentang Kepailitan Lembaran Negara Republik Indonesia Tahun 1998 Nomor 87, Tambahan Lembaran Negara Republik Indonesia Nomor 3761.

Undang-Undang Republik Indonesia Nomor 4 Tahun 1998 tentang Penetapan Peraturan Pemerintah Pengganti Undang-Undang Nomor 1 Tahun 1998 tentang Perubahan Atas Undang-Undang tentang Kepailitan Menjadi Undang-Undang Lembaran Negara Republik Indonesia Tahun 1998 Nomor 135 Tambahan Lembaran Negara Republik Indonesia Nomor 3778.

Undang-Undang Republik Indonesia Nomor 37. Tahun 2004 tentang Kepailitan Dan Penundaan Kewajiban

Pembayaran Utang Lembaran Negara Republik Indonesia Tahun 2004 Nomor 131, Tambahan Lembaran Negara RepublikIndonesia Nomor 4443.

\section{Website}

http://www.jurnalhukum.com/2-hal-yang-mengakibatkan-telkomsel- pailit/, diakses tanggal 03 Januari 2013

http://ocw.usu.ac.id/course/download/10430000019-hukum-transaksibisnis-

internasional/hk_607_slide_kepastian_hukum_dalam_transaksi_ bisnis_internasional_dan_implikasinya_terhadap_kegiatan_inve stasi_di_indonesia.pdf., diakses tanggal 9 Juni 2013

http://nasional.kontan.co.id/news/telkomsel-ajukan-proposal-perdamaian, diakseas tanggal 9 Juni 2013.

http://tekno.kompas.com/read/2012/11/02/16472299/Kurator.Siap.Perte mukan.Telkomsel.dengan.Prima.Jaya, diakses tanggal 9 Juni2013.

http://www.bisnis-jatim.com/index.php/2012/10/31/pailit-telkomsel- debiturbelum-siap-verifikasi-utang-ditunda/, diakses tanggal 9Juni 2013.

http://www.bisnis-kepri.com/index.php/2013/02/prima-jaya-ajukanpeninjauan-kembali-telkomsel-masih-terancam-pailit/,diakses tanggal 9 Juni 2013. 